$\xi=$ 圈

\title{
The ambivalence of santiago a psychoanalytic study
}

\author{
T. S. Sujatha * \\ Research Scholar, AMET University \\ *Corresponding author E-mail: coe@adhi.edu.in
}

\begin{abstract}
Santiago, the protagonist of the American novelist, Ernest Hemingway's novella, The Old Man and the Sea is certainly a sphinx amongst complex characters in fictional literature. A true understanding of this very puzzling character is beyond the scope of the conventional study methods of critical reading, critical analysis, critical appreciation etc. Only a psychoanalytic approach offers us some prospect of being able to understand the dichotomy between the psyche and the persona of Santiago. However, it needs to be emphasized here that the psychoanalytic approach is neither superior nor inferior to the other approaches. It is only a very different kind of approach that promises new possibilities. Its application is justified when our subject of study happens to be a complex character like Santiago. We also need to remain alert and wary of the fact that a pseudo-psychoanalytic study can easily lead to absurd understandings. This paper reports a study of Santiago's character based specifically on Freudian Classical Psychoanalytic Theory of Personality. At the same time, however, it does not altogether disregard or discount Jungian or Lacanian psychoanalyses. The objective of this paper is to explain in psychoanalytic terms how Santiago is saved from becoming dangerously paranoid, schizoid and maniacal.
\end{abstract}

Keywords: Id; ego; Superego; Oedipus complex; Sublimation; Ambivalence; Life Principle; Death Drive.

\section{Introduction}

This paper divides into three parts. Part-I - (Literature Review) reviews certain fundamental concepts in psychoanalytic theory which are considered germane to this study. Part-II - (Discussion) examines (1) the climactic event of the novella -Santiago's struggle with a marlin (2) his ambivalence (3) the fantasy of his dinner ritual (4) his recurring dream of African lions and (5) the death drive as the most influential motivational force behind his thoughts, words and actions in the light of the concepts enumerated in Part I. In Part III- (Conclusion), the author proposes that while it is true that the character of Santiago is in the tradition of the great classical heroes of ancient literature notwithstanding the fact that he is a humble fisherman, what really motivates his behaviour is the death drive in his unconscious.

The Old Man and the Sea, Ernest Hemingway's last major work of fiction is a novella published by Charles Scribner's Sons in 1952. It won for him the Pulitzer Prize for Fiction in 1953.

In the novella, Hemingway touches upon many great themesman's place within nature, the struggle for honor in existence, for pride in defeat, for dignity in death etc. But more than the powerful themes it contains and more than the merits of his famed prose style in the masterful telling of this moving sea story, it is the complexity in the character of Santiago arising out of his ambivalence that makes The Old Man and The Sea a compelling classic of our times.

The story

Santiago is an old Cuban fisherman who has not caught any fish for 84 days. Manolin, a young boy, is his friend. The boy often helps the old man with food.Otherwise the old man would have died of starvation long ago.

One day the old man wakes up after dreaming of African lions and heads out for fishing in the Gulf Stream. After a great struggle he catches a marlin - a very large kind of fish. He ties the fish to the side of his boat and returns home. But on the way some sharks attack his boat and start eating the marlin. The old man tries to beat them off with a harpoon, a club and a knife. However, by the time he returns to the shore, there is nothing left of his marlin except its skeleton. He goes to sleep and dreams of African lions.

\section{Literature review}

There have been many psychoanalytic studies of Hemingway's writings that are truly thought - provoking and deserving of careful consideration such as A Lacanian Analysis of Hemingway's Search for Spirituality (Mandy Guttmann-Gonzeles, 2013) and The concept of Thanatos in Hemingway's Novels (Nemotolla Moradi and Dr.Lingaraj Gandhi, 2007) or Destroyed but not defeated: Hemingway's The Old Man and the Sea: A psychotherapeutic story (Saeed Momtazi M.D, 2003). Another perceptive study is The Old Man and the Sea: Hemingway's Tragic Vision of Man (Clinton S. Burhans, Jr. 1960). Humor after Eclipse, a comparative study of Hemingway's novella and a Slovenian adaptation of the novella by Dolenc (Alenca Jovanovski, 2013), contains some insightful observations on the delusional ego-images of Santiago. Against this background, this author felt that it would be not only useful but also necessary to address the issues implied in the following observation: "It is not necessary (or even possible) to understand the complex universe - it is enough for Hemingway's heroes to find solace in beauty and order. Santiago in The Old Man and the Sea cannot understand why he must kill the great fish he has come to love, Burhans noted. Hemingway described Santiago's confusion: "I do not understand these things, he thought. But it is good we do not try to kill the sun or the moon or the stars. It is enough to live on the sea and kill our true brothers". (POETRY FOUNDATION, 2013). On his own admission, Santiago has no understanding of the ambivalence underlying his love of the marlin he wants to kill. This ambivalence of Santiago is extreme 
to such an extent that it could well be diagnosed and identified as being pathological. Yet we find nothing in the novella to suggest that there is anything pathological about him. This paper seeks to explain the paradox of this situation and to show how Santiago's extreme ambivalence which is potentially very dangerous to him as well as to others is however, luckily, prevented from actually becoming pathological.

Sigmund freud (1856 -1939)

That an individual's unconscious mental processes do motivate and influence his behaviour is the central tenet of psychoanalysis. Sigmund Freud is the founder of psychoanalysis and its most influential exponent. According to him, the human mind functions at two levels - the conscious and the unconscious. At the conscious level, people are aware of their thoughts, feelings and reasons for their actions. At the unconscious level, they have no such awareness or understanding or access to the many complex processes going on in their minds at any given point of time. There is enough evidence in psychological research to suggest that much of human behavior is motivated by deep unconscious urges that people remain unaware of. In Id, Ego and Superego Saul Macleod (2007 updated 2016) points out how, according to Freud, the human personality or psyche has a tripartite structure consisting of the id, the ego and the superego. However, these are only systems of the mind. There is nothing physical about them.

Carl jung (1875 - 1961)

Carl Jung, another celebrated psychologist who influenced the psychoanalytic movement, held views that were somewhat different from those of Freud. Like Freud, Jung also believed in the tripartite structure of the human psyche. But he believed that the three parts of the mind were the ego, the personal unconscious and the collective unconscious. Jung believed that the symbols of dreams and religions gave us insights into the unconscious. Besides, Jung's work has also led to our understanding of personality types of people in real life as well as fictional characters in literature.

Jacques lacan (1901-1981)

According to the French psychoanalyst, Jacques Lacan's psychological theory, there are three major stages in an individual's psychological development. They are: (1) the Real stage which begins at birth and during which the child feels a deep sense of oneness with the mother, (2) the Imaginary stage or the mirror stage when the child acknowledges itself to be separate from the mother and (3) the Symbolic stage which is associated with the father figure, when the child is born into language and society. Lacan "was interested in what happens between words and lines, with the margins of the psyche, with an unconscious i.e. that art of the word that fails. Lacan is therefore considered the most controversial psychoanalyst since Freud" (Mokaya).

The id

According to Freud (Hall and Lindsey: 1957:32), id is "the original system of personality where ego and superego become differentiated and consist of everything psychological that is inherited" Also, according to Freud (Bressler, 1998:150), id is "the irrational instinctual, unknown, and unconscious part of the psyche". It remains infantile throughout one's life. It remains uninfluenced and unaffected by the changes caused by the processes of growth of an individual. The id operates or acts mainly on what is known as the pleasure principle which demands that every single impulsive wish or desire of the individual be satisfied immediately regardless of consequences. Any denial or failure of such satisfaction leads to the individual experiencing tension.

The ego

According to Freud (1962:18), the ego "recognizes what is real and understands that behaviors have consequences to live and socialize with other people" The ego develops out of the id influenced by the forces of the external world as felt by the individual in his day to day life.It operates or acts according to the reality principle as opposed to the pleasure principle of the id. The ego is realistic and wants to protect the individual from the harm of negative social consequences of bad behavior. On the other hand, the id is unreasonable and chaotic.
It always goes by the pleasure principle irrespective of consequences. It generally gets the better of the ego which tries to hold the forces of the id in check. The ego is ready for compromises, unlike the uncompromising id. In Id, Ego and Superego, Saul Macleod (2007, updated 2016) points out how "Freud made the analogy of the id being the horse while the ego is the rider who has to hold in check the superior strength of the horse".

The superego

According to Stey and Lapsley (2011:6-7), the superego is "the conscience which punishes the ego through causing feelings of guilt".

It reflects the ethical or moral values of the society in which the individual lives and represents his ideal self. The superego causes feelings of guilt in the individual whenever the ego fails to control the impulses of the id which, according to it, are harmful to the individual. The superego also makes an individual feel proud when his behavior is approved by it.

The death drive

In a paper entitled Freud's Concept of the Death Drive and its relation to the Superego, Joanne Faulkner (153-176) clearly brings out several of Freud's views on the death drive, the pleasure principle, sublimation, dreams, sadism, masochism etc. According to her, in Freud's view, the death drive is opposed to the life drive. The life drive seeks to promote the survival prospects of cells by building them into greater and greater bodies. Pleasure is implied and exists in this promotional process. On the other hand, the death drive seeks to reverse this process and to bring about a disintegration of cells for the purpose of restoring them (the cells) to their original state of ultimate equilibrium (death). Paradoxically, according to Freud, this opposite process implies a pleasure greater than the pleasure experienced in the processes of the life drive. These biological tendencies have had a role to play in the evolutionary history of every species including that of the Homo sapiens.

They still survive in us in our unconscious - as an inheritance from a primordial past. The death drive is more primordial than the life drive. Eros (life) emerges from Thanatos (death) as its outward manifestation. According to Freud, there is something in our unconscious that believes that life is only a means to death which is the real end. The seed of destruction (death drive) that lies deep within us alone can explain the phenomena of masochism and sadism in humans. The life drive and the pleasure principle cannot adequately account for them.

The fact that civilized people can nevertheless go to war which entails the pain of death and destruction need not baffle us so long as we are ready to accept and acknowledge the fact that the death drive really exists as a potentially powerful force deep down within us and our psyche. Our understanding of the drive becomes broader and clearer when we place it in the context or perspective of another human phenomenon known in psychology as sublimation.

\section{Sublimation}

In psychoanalytic theory, sublimation is a type of defence mechanism which involves a desexualisation of libidinal energy. This energy is discharged in such activities as creative writing, religious worship, art, music etc. In The Ego and the Mechanisms of Defence (1936), Freud's daughter. Anna, classes' sublimation as one of the major 'defence mechanisms' of the psyche. Sublimated energy may also be exploited by the death drive to find expression in acts of aggression or destruction. While sublimation accounts for our creativity at its best (enhancing our pleasures) it also accounts for our destructiveness at its worst (deepening our pains).

The oedipus complex

One other closely related concept in psychoanalysis which we need to consider here is the Oedipus complex. Faulkner refers to Freud's essay "The Dissolution of the Oedipus Complex"(1924) in which he makes several important statements on the subject. Around the age of three to five years children are attached with incestuous love for the parent of the opposite sex (object - cathexis) combined with a sense of rivalry and a desire to replace (by destroying) the parent of the same sex who prohibits its incestuous 
love. This phase normally ends when the child identifies with and internalizes the parent of the same sex. This identification involves the process of sublimation and the emergence of the superego that enables the child to take its place in society. The growth of the child (and the growth of its personality) involves a series of sublimations and many parental figures or authorities.

When sublimation takes place libidinal energies are repressed, desexualized and deflected towards non-sexual goals. We should remember that the process of sublimation involves only a repression and not an elimination of libidinal energies. The death drive exploits this situation so that the sublimated energies are expressed not only in creative activities of cultural value but also in acts of aggression or destruction (and war). The ambivalence in this situation only reflects the ambivalence in the love-hate relationship of the child vis - 'a -vis the parental figure in the Oedipus complex.

Dreams

Initially, Freud believed that one of the purposes of dreams was wish-fulfilment. Later on, however, he noted that the idea of dream as wish -fulfilment did not adequately explain why a war veteran returned again and again to his dream of fighting in a war an obviously painful experience. It is difficult to believe that anyone would welcome a painful experience even in a dream unless we also assume the existence within ourselves of a drive other than the life drive and the pleasure principle. According to Faulkner, the drive appears to circulate about a point of pure pain that is neither ejected from, nor neutralized by, the psychic system as the pleasure principle demands, and in fact attracts rather than repels the subject (p: 156).Further, Freud believed that the death drive existed in the human psyche as the most concealed element of the unconscious residing beyond the pleasure principle and further that a compulsion to repeat signaled this drive.

Ambivalence

Ambivalence is seen in the behavior of people when they experience mixed feelings in response to a given situation. Or it may be seen in the conflicting beliefs or attitudes of people expressed or demonstrated in their interactions with other people. Extremely ambivalent actions, reactions or attitudes expressed or reflected in love -hate relationships are bound to impact our lives negatively and adversely. According to Leon F Seltzer PhD (Evolution of the Self: posted Feb 12, 2014) individuals struggling with ambivalence are "almost literally of two minds" and are not "anxietyfree".

\section{Methodology}

Santiago's views, beliefs, hopes, fears etc. as expressed in his statements, self-talk, conversations with sea creatures (monologues),his attitudes reflected in his behavior towards Manolin and his "true brothers" - the fish and other sea creatures including sea birds - his memories, fantasies and his lion dreams - in short, all that he thought, said and did in the course of the novella, prior to, during and after the ordeal of his expedition in his skiff into the sea in the hope of a big catch were studied and examined in detail in a psychoanalytic perspective. The objective of the study was (1) to assess and determine the extent to which the above revealed or reflected his ambivalence and his death drive and (2) to identify factors, if any, which saved his ambivalence from becoming pathological.

\section{Discussion}

\section{Santiago and the marlin}

The climactic event of The Old Man and the Sea is Santiago's encounter and great struggle with the marlin and his killing of the fish. Repeatedly during this struggle, Santiago acknowledges and expresses his respect and love for the fish and its pride, courage and nobility. He considers the marlin to be a worthy opponent. He even says that those who will eat its meat are unworthy of it. His empathy and admiration for the marlin are genuine. He believes that the marlin is not just a fish - not just another sea creature. It is his 'brother' -in suffering, proud and noble like himself. Yet he wants to kill it. And he is also ready to be killed by it. You are killing me, fish, the old man thought. But you have a right to. Never have I seen a greater or more beautiful, or a calmer or more noble thing than you, brother Come on and kill me. I do not care who kills who (p: 35)

"I'II kill him though," he said "In all his greatness and his glory." (p: 35).

While he pledges his love and respect to the fish,he must kill it before the day ends. Why would Santiago want to kill "a brother" whom he loves? After killing the marlin, Santiago reminds himself that he did not kill it simply for food but out of love. He wonders whether it is a sin to kill something that one loves.

In all this discussion and debate, argument and counter -argument, there is only one pertinent question we need to ask. How does one reconcile loving and killing except by believing that the one entails the other. It is the need for such reconciliation that accounts for Santiago's ambivalence in wanting to kill the marlin, his beloved "brother".

Two important observations need to be made here.

1) The relationship between Santiago and the marlin is like the relationship between two human beings. It is not just a relationship between a fisherman and a fish. When Santiago says that the marlin is his brother, he is only saying what he believes to be true. When he refers to fish as "our true brothers" he is only saying what he believes to be true. It follows therefore that, when he kills a fish like the marlin, it is as though he has killed another human being. Does it not also follow, therefore, that a lifetime of fishing is a lifetime of killing people?

2) To Santiago, killing is important - not who kills whom. When he thinks that the marlin is killing him, he actually admires it for wanting to kill him. He says, "I do not care who kills who" (p: 35).

Santiago's ambivalence

santiago's attitude towards the marlin and his relationship with it are clearly ambivalent.

santiago's ambivalence is a problem. However, it is not a problem in the sense that it detracts from the merits of heming way's novella in any way. on the contrary, it is one of the big pluses of the novella which determines what makes the character of santiago unique and, therefore, fascinating to us. the real problem is in understanding what makes santiago ambivalent now.is it a throwback to a critical phase of his early childhood - to his oedipus complex?

\section{Santiago's fantasy}

What are we to make of this conversation between Santiago and Manolin at the beginning of the novel?

"What do you have to eat?" the boy asked.

"A pot of yellow rice with fish.Do you want some?"

"No. I will eat at home.Do you want me to make the fire?"

"No. I will make it later on. Or I may eat the rice cold"

"May I take the cast net?"

"Of course".(P:4)

We know that in reality there was no yellow rice to eat and that there was no cast net either because we know also that it had already been sold. Why do Santiago and the boy regularly indulge in this dinner ritual fantasy?

It has already been mentioned elsewhere in this paper how the id is made up of our instinctual urges one of which is the instinct for survival and how the id perpetually seeks pleasure according to the pleasure principle. Santiago's fantasy about yellow rice may be seen as an expression of the pleasure principle that is active in his id. It is a fact of life that all of us make efforts not only to satisfy our instinctual needs but also to satisfy our craving for pleasures according to the pleasure principle of the id. We need to eat in order to survive. We also know that eating good food is one of the pleasures of life. When we fail to meet our needs or fail to satisfy our craving for pleasure, we tend to resort to fantasizing for wish-fulfilment. We fantasize about an event or situation when we 
know that it is not true and that, therefore, it is unlikely to happen. We fantasize about it to give ourselves pleasure by imagining that it is in fact true and actually happening. This is one way to look at Santiago's dinner ritual fantasy.

However, considering Freud's view that a compulsion to repeat signals the death drive, a more plausible explanation would be that Santiago's fantasy is actually a celebration of his deprivation which will expedite the realization of a cherished goal which is reaching a state of primordial inertia (death).Also, this dinner ritual fuses the pain of deprivation with the pleasure of fantasizing. Masochism is very much in evidence here.

Santiago's dream of african lions

The same compulsion to repeat is evident in Santiago's recurring dream of African lions on the beach. This dream also suggests more than the fulfilment of his simple wish to retrieve lost youth Lions are predatory animals which live and survive by killing other animals for food. What are we to make of these lions of Santiago's dream which do not hunt but prefer to be playful like young cats in the dusk? The fatal attraction of their playfulness foreshadows their impending death by starvation. Far from being a simple wish-fulfilment dream, Santiago's dream of African lions is an ominous death wish-fulfilment dream. But what is the wish that is sought to be fulfilled through this dream? Is Santiago wishing for the death of the lions? Or is he wishing for his own death? In any case, what is unmistakable in the dream is Santiago's death drive.

Santiago and the death drive

As already mentioned elsewhere in this paper, Freud believed that the death drive existed in the human psyche as the most concealed element of the unconscious residing beyond the pleasure principle and further that a compulsion to repeat signaled this drive.

Considering that repetition and recurrence assume great significance in psychoanalysis and that repetition also characterizes the Obsessive Compulsive Disorder (OCD), it is significant that in the novella Santiago's dinner ritual is repeated. His dream of African lions is repeated. His declaration of love for fish is repeated several times in his statements. The theme of death is repeated in his thoughts and monologues.

There is a consensus in psychoanalytic theory, that the death drive may manifest itself either as a suicidal desire for one's own death or as a homicidal desire for the death of someone else. It may also appear as aggressive or destructive behavior in sadism (experiencing pleasure by causing pain and suffering to others) or in masochism (experiencing pleasure in one's own pain and suffering).

However, the ultimate goal of the death drive is not to experience pain but to reach a state of primordial inertia (death) which, Freud asserts, is a pleasure in itself beyond the pleasure principle. If that is the case, then, surely, such a pleasure can only be bliss.

If A wants to die because he believes that the pain of such death will in fact be a pleasure to him, then $A$ is a suicidal masochist.

If $A$ causes the death of $B$ because he believes that such death, though a pain to $\mathrm{B}$, will be a pleasure to himself $(\mathrm{A})$, then $\mathrm{A}$ is a homicidal sadist.

If A causes the death of B because he believes that such death will give pleasure to B himself, then A is a good Samaritan, an altruist motivated by the death drive in his psyche.

\section{Conclusion}

As mentioned earlier in this paper, extreme ambivalence in an individual is harmful because it exposes him to negative social consequences. The consequences of pathological ambivalence could be far worse. This study shows that Santiago is an extremely ambivalent individual who loves to destroy- (kill) - what he loves - his "true brothers" (the fish).However, there is nothing in the novella to suggest that Santiago's ambivalence has harmed him in any way. There is nothing pathological about his ambivalence. On the contrary, the many ambivalences, dichotomies and eccentricities in his strange meditations, articulations and obsessively idealistic concerns - as identified in this study — show him to be a unique individual with a superego that baffles us belying his humdrum existence as an old Cuban fisherman who has not caught a fish for days.

How do we explain the paradox of this situation? The answer is not in Santiago's ambivalence itself or in his death drive itself but in the richness of the sublimations issuing from the drive and informing his superego. This is what explains his lofty idealism, his complete identification with all of life and nature and his deep spiritual orientation which is far removed from religious dogmatism.

This author proposes that although, Santiago is apparently just an ordinary fisherman, he actually saw himself subconsciously as a Messianic figure fixated on the belief that he must liberate humanity from the pain of living by gifting them the pleasure of dying. He was a fisherman - symbolically, fishing humans. Underlying his vision and mission is the death drive concealed in his magnificent obsession to enable his "true brothers" to find their salvation in the ultimate equilibrium of death. Hemingway's deliberate choice and repeated use of Christian imagery and symbols in the narration of events especially during the climactic moments of the novella and towards its end (the stigmata on the body of Santiago, his pain and suffering, the suggestion of the cross and crucifixion of Christ) validate this proposition. Santiago is not a devout Christian. Yet he is Christ-like. We see in him the near-mythical proportions of the great classical heroes of literature notwithstanding the fact that he is a humble fisherman.

However, it is important to note that Santiago's credo remains subdued and embedded in his healthy ego-bound self-image of a common Cuban fisherman struggling for his existence. Otherwise it would have sought an outlet in dangerous maniacal excesses harmful to himself as well as to the society of which he is a part.

If psychoanalysis is the treatment of someone who has mental problems by asking them about their feelings and their past in order to try to discover what may be causing their condition, then it would be true to say that Santiago cannot be psychoanalyzed. However, this author's experience of this research study shows that it is possible to interpret his thoughts, words and actions in the light of the principles of psychoanalysis. This paper reports such an interpretation. Unless timely preventive action is taken, ambivalence, if it is also combined with aggressiveness, can make an individual dangerously paranoid, schizoid or maniacal. However, according to this study, though Santiago is ambivalent to an extreme degree, he still remains a healthy individual retaining his great optimism till the very end despite the many trials and tribulations of his life. This can only be explained in terms of the sublimations that inform his superego. In conclusion, it is also asserted here that only a psychoanalytic study can explain Santiago's ambivalence adequately and convincingly.

Acknowledgement

This paper is written in partial fulfilment of requirements for the award of the degree of $\mathrm{PhD}$ in English Literature at the AMET University, Kanathur, Chennai - 603112 .

This author wishes to acknowledge all the support received from the University and to thank Dr. Kanagamani Balasubramaniyam, Head of the Department of English and Research Supervisor for all her kind guidance in carrying out this research on Ernest Hemingway's The Old Man and the Sea at the University.

\section{References}

[1] Blesser CE, Literary Criticism. An Introduction to Theory and Practice United States of America: Houghton College, (1998).

[2] Ernest H, Scribner, the Old Man and the Sea. Novella New York, (1952)

[3] Freud S, the Ego and the Id (The Standard Edition of the Complete Psychological Works of Sigmund Freud). N.Y., New York. W.W. Norton and Company, (1962).

[4] Freud A, the Ego and the Mechanisms of Defence, Karnac Books Ltd, 118 Finchley Road London NW3 5HT, (1936).

[5] Stay P \& Lapsley DK, Ego and Superego. University of Notre Dame: Elsevier, (2011). 


\section{Internet references}

[1] Faulkner J, Freud's Concept of the Death Drive and Its Relation to the Superego, (2005).

[2] McLeod SA \& Carl J, www.simplypsychology.org/carljung.html (2014).

[3] McLeod

$$
\text { SA \& Superego }
$$

E, (2016).www.simplypsychology.org/psyche/html

[4] Seltzer LF, https://www.psychologytodaycom/experts/leon-fseltzer-phd, (2014).

[5] Mandy GG, A Lacanian Analysis of Hemingway's Search for Spirituality. https://www.visiblepoetryproject.com, (2013).

[6] Saeed Momtazi MD, Destroyed but not defeated: Hemingway's The Old Man and the Sea: A psychotherapeutic, Story, https://www.researchgate.net/profile/Saeed_Momtazi, (2003).

[7] Alenca J, Humor after Eclipse. https://www.dnevnik.si/ 1042660088, (2013)

[8] Clinton SB, Hemingway's Tragic Vision of Man, https://www. jstor.org/stable/2922437, (1960).

[9] Nemotolla M \& Lingaraj G, The concept of Thanatos in Hemingway's Novels, www.uni-mysore.ac, (2007).

[10] Poetry Foundation (2013) Ernest M. Hemingway (1899-1961), (https://en.wikipedia.org/wiki/Ernest_Hemingway)

[11] Mokaya N Freudian \& Lacanian. Psychoanalyses: A Comparison and Contrast, www.academia.edu/.../FREUDIAN_AND_LACAN IAN_PSYCHOANALYSES_A_CO,(2017). 